\title{
CELLULAR AUTOMATON WITH PERCOLATION AS A DYNAMIC SYSTEM: ENTROPY APPROACH *
}

\section{V.A. Shvedovskiy}

MSU M. V. Lomonosov, Faculty of Computational mathematics and Cybernetics, Moscow, Russia

$\square$ mamosp@mail.ru

A model of information confrontation based on a two-dimensional percolation-cellular automaton on a closed oriented surface is constructed and implemented programmatically. Numerical experiments were performed. A theorem on the finiteness of a completely positive topological entropy of a given cellular automaton is formulated and proved. As an applied application of the constructed automaton, a retrospective forecast of the results of the Russian Presidential election in 2018 was made both in Russia as a whole and in two regions of Russia. The General logic of using the automaton was as follows. At the preparatory stage, a model of the region was built, which is a field of a cellular automaton. In the case of regions, anamorphic mapping was used, in which each territorial-administrative unit is represented by a certain number of cells that occupy a connected area of the field of the automaton; the areas of these areas are proportional to the number of voters, and if possible, geographical neighbors are preserved. The color of the cell corresponds to a certain political position; for example, if a certain city has $60 \%$ support for the President, then this percentage of cells in that city is red. As initial data for the calculation, the results of sociological surveys on support for the current President conducted 6-12 months before the election were taken; the dynamics of the system is modeled using a cellular automaton; for the formed stationary solution, the shares of cells corresponding to the number of supporters and opponents of the President, as well as non-appearance, are calculated; these shares are taken as a forecast of election results. Those constructed in this way showed significantly lower accuracy than forecasts made using standard sociological methods in the last days before the election. However, they can be used for early forecasting. The reason for this difference is that the opinions of voters immediately prior to elections are determined by campaign, and long before the election - the prevalence and embeddedness of value orientations, which is incorporated in the model.

Keywords: cellular automaton, percolation, anamorphosis, topological entropy, value orientation, forecast, index of embeddedness of codes.

Introduction: motivation for turning to cellular automaton. «Hybrid war», aimed at changing the enemy's undesirable regime, allows for a wide range of instruments of influence: from the so-called «soft power» to the introduction of occupation troops. Information and psychological attacks via the Internet take their place in this spectrum. One of the most important areas of their research is the mathematical study of information warfare [1-6].

The key target of information attacks in today's Russian society is public opinion about the government. They sow doubt about its legitimacy and prepare this opinion, as well as the international one, in their favor.

Therefore, it is critical to know its dynamics. The paper models this process based on multi month data (VTSIOM, FOM, Levada Center, etc.). Example of a non-point model is the attitude of

\footnotetext{
* The reported study was supported by Russian Foundation for Basic Research (project 20-01-00229).
} 
the population to its President in the form of a lattice dynamic system - L. D. S. (taking into account spatial coordinates) of interacting pro\&contra factors, including information warfare. The fundamental problem here is the acceptable accuracy of the forecast, in which the training sequence is based not on a number of election days, as in Gallup - with an error of less than 2-3\%, but on a set of preliminary months and with an error of an order of magnitude worse. The problem was solved on a programmed Murov cellular automaton with percolation. Computational experiments-CE on it have shown that its operation can be considered as an action of the ergodic automorphism of L. D. S. [7]. However, as shown by V. A. Rokhlin and Ya. G. Sinai [8], its entropy is often equal to 0 or $\infty$, and sometimes it is finite and completely positive.

Therefore, in addition to applied problems, this research project had a theoretical motive: justification of the limb quite positive topological entropy $[8,9,10,11]$ have L. D. S., the study of the effects on it kind of a two-dimensional surface (the degree of connectedness of society) and the calculation of its values for the accuracy of this forecasting tool.

Description of the cellular automaton with percolation and working with it. Predicting the balanced attitude of the Russian society to its President is based on two groups of facts - a) data from measurements by sociological services (see above) of the trust in him of various social groups, and b) the results of EE with cellular automata tuned to these data, i.e. L. D. S. Cellular automata (here PCA - percolation-cellular automata) are a simulation of Russian society by a multi-agent environment of interacting cells divided into 4 sets (one constant, i.e. unchanged in the number of cells and their coordinates, - «white»-apolitical contingent; 3 variables (in all senses): $\mathrm{r}-\langle$ red»traditionalists, $\mathrm{v}-\langle$ blue» - liberal orientation, and $\mathrm{b}-\langle$ black» - with ideological porridge in your head. At the same time, each color cell representing a social subject (individual, group, etc.) has a third dimension - the depth of adherence to the corresponding orientation, indicated by the above colors; «black cells» are characterized by a single depth, i.e. this is the fruit of the balance of the impact of lternative positions, but their positional status is that they do not miss the influence of colored cells - the status of white cells - until the balance is replaced by the dominance of some color with the restoration of its status.

The working field of the PCA (WF PCA) is a two-dimensional regular lattice with the Moore type of intercellular interaction at $\mathrm{r}=2$. Cells of "white color" are essentially defects in the regularity of the lattice, because they are unchanged during the re and do not pass through their positions any influence of colored cells. The scenarios also involve modeling the impact of media on the "life of cells" by connecting channels of the corresponding color to different points of the grid, taking into account their numerical ratio and the nature of distribution on the WF PCA.

Percolation-cellular automaton as a lattice dynamical system. Definition 1. Discrete dynamical system $\left(\mathrm{F}^{\mathrm{n}}, \mathrm{B}\right) \mathrm{n} \in \mathrm{Z}^{+}$called lattice dynamical system - L. D. S. and recorded

$$
(u(n+1))_{j}=F\left(\left\{(u(n))_{j}\right\}^{n}\right)
$$

where

$$
\left\{(u(n))_{j}\right\}^{n}=\left\{(u(n))_{i}|| i-j \mid \leq s\right\} ;(s \geq 1) \in Z^{+}, j \in Z^{d}
$$

and F: $\left(E^{p}\right)^{(2 s+1)^{d}} \rightarrow E^{p}$ is a differentiable map of Euclidean space to itself class $C^{2}$ such that $\left|\partial F / \partial u_{i}\right| \leq M 1,\left|\partial^{2} F / \partial u_{i} \partial u_{j}\right| \leq M 1$ for any set $\left\{u_{0}\right\}^{s}$. 
Definition 2. Cellular automaton - CA will be considered as given, if for L. D. S. the following conditions are met:

1) is considered as self-contained discrete dynamical system a two-dimensional field, where $\mathrm{Z}^{2}$ similarly shows the relationship of interaction between the units of society in its natural sociogeographical field.

2) PCA-type L. D. S. is considered as an object of the entropy approach of ergodic theory. Moreover, the output of the PCA to the equilibrium plateau (see Fig. 2 and 3) is interpreted as the presence of a stationary mode.

3) Local rules for interaction of colored cells for $\mathrm{r}=2$ contain the following expressions:

$$
\begin{gathered}
y_{i, j}{ }^{k}(n+1)=f\left(\begin{array}{c}
y_{i-2, j-2}(n)^{k}, y_{i-1, j-2}(n)^{k}, y_{i, j-2}(n)^{k}, y_{i+1, j-2}(n)^{k}, y_{i+2, j-2}(n)^{k}, \\
y_{i-2, j-1}(n)^{k}, y_{i-1, j-1}(n)^{k}, y_{i, j-1}(n)^{k}, y_{i+1, j-1}(n)^{k}, y_{i+2, j-1}(n)^{k}, \\
y_{i-2, j}(n)^{k}, y_{i-1, j}(n)^{k}, y_{i, j}(n)^{k}, y_{i+1, j}(n)^{k}, y_{i+2, j}(n)^{k}, \\
y_{i-2, j+1}(n)^{k}, y_{i-1, j+1}(n)^{k}, y_{i, j+1}(n)^{k}, y_{i+1, j+1}(n)^{k}, y_{i+2, j+1}(n)^{k}, \\
y_{i-2, j+2}(n)^{k}, y_{i-1, j+2}(n)^{k}, y_{i, j+2}(n)^{k}, y_{i+1, j+2}(n)^{k}, y_{i+2, j+2}(n)^{k}
\end{array}\right) \\
k= \begin{cases}r & \text { if } \Delta^{r, v}\left(y_{p, q}^{k}\right)=\left(\sum_{i, j} y_{i, j}^{r}-\sum_{i, j} y_{i, j}{ }^{v}\right)>0 \\
b & \text { if } \Delta^{r, v}\left(y_{p, q}^{k}\right)=\left(\sum_{i, j} y_{i, j} r-\sum_{i, j} y_{i, j}{ }^{v}\right)=0, \\
v & \text { if } \Delta^{r, v}\left(y_{p, q}^{k}\right)=\left(\sum_{i, j} y_{i, j}^{r}-\sum_{i, j} y_{i, j}{ }^{v}\right)<0\end{cases}
\end{gathered}
$$

where

$$
\begin{array}{r}
y_{p, q}^{k} \in\left\{\begin{array}{c}
y_{i-2, j-2}(n)^{k}, y_{i-1, j-2}(n)^{k}, y_{i, j-2}(n)^{k}, y_{i+1, j-2}(n)^{k}, y_{i+2, j-2}(n)^{k}, \\
y_{i-2, j-1}(n)^{k}, y_{i-1, j-1}(n)^{k}, y_{i, j-1}(n)^{k}, y_{i+1, j-1}(n)^{k}, y_{i+2, j-1}(n)^{k}, \\
y_{i-2, j}(n)^{k}, y_{i-1, j}(n)^{k}, y_{i, j}(n)^{k}, y_{i+1, j}(n)^{k}, y_{i+2, j}(n)^{k}, \\
y_{i-2, j+1}(n)^{k}, y_{i-1, j+1}(n)^{k}, y_{i, j+1}(n)^{k}, y_{i+1, j+1}(n)^{k}, y_{i+2, j+1}(n)^{k}, \\
y_{i-2, j+2}(n)^{k}, y_{i-1, j+2}(n)^{k}, y_{i, j+2}(n)^{k}, y_{i+1, j+2}(n)^{k}, y_{i+2, j+2}(n)^{k}
\end{array}\right\}, \\
\mathrm{p} \in\{i-2, i-1, i, i+1, i+2\} ; q \in\{j-2, j-1, j, j+1, j+2\} ; i, \mathrm{j} \in Z^{2}
\end{array}
$$

We determine the depth of States of each active cell - its «number of lives» $-\mathrm{Y}_{0}=\{1, \ldots, \mathrm{p}-1\}$, $\mathrm{p} \geq 2$; for the considered PCA, $\mathrm{p}=10$.

$$
\operatorname{sgn}\left(Y_{0}\right)=\left\{\begin{array}{cl}
1 & \text { if } \boldsymbol{r} \\
0 & \text { if } \boldsymbol{b} \\
-1 & \text { if } \boldsymbol{v}
\end{array}\right.
$$

Enter $y_{i, j}^{r, v}=y_{i, j}^{r, v} \times \operatorname{sgn}\left(Y_{0}\right), \mathrm{i}, \mathrm{j} \in Z^{2}$.

By a random law and with the chosen density, the coordinates are set; $i^{\prime}, j$ ' $\in Z^{2}$ for the white cells of the WF PCA. Next, we proceed to the construction of symbolic images of a discrete dynamical system, that occurs during a computational experiment (CE) with PCA.

Symbolic image of a discrete dynamic system of the PCA type. Let $f: M=M$ is a homeomorphic map of the compact to itself, and $C=\{M(1), M(2), \ldots, M(n)\}$ is a finite cover by a closed set of the compact $M$. the Sets $M(i)$ are the cells of the cover. For each number $i$, we assign a sub-cover $C(l 1)$ of the image of cell $M(l 1)$, consisting of those cells $M(l 2)$ that intersect it:

$$
C(l 1)=\{M(l 2): M(l 2) \cap f(M(l 1)) \neq 0\}
$$

The set $C(l 1)$ is defined as the cells $M(l 1)$ :

$$
c(l 1)=\{l 2: M(l 2) \cap f(M(l 1)) \neq 0\}
$$


Definition. Let $\mathrm{G}$ be a digraph with $\mathrm{n}$ vertices whose $\mathrm{i}$-th vertex corresponds to the cell $\mathrm{M}(11)$ as in Fig. 1. the Vertices 11 and 12 are connected by an arc if $M(12) \cap \mathrm{f}(\mathrm{M}(11) \neq 0$. then the digraph $\mathrm{G}$ is a symbolic image of the map $\mathrm{f}$ with respect to the cover $\mathrm{C}[9,13]$.

\begin{tabular}{|c|c|c|c|c|}
\hline 1 & & 17 & 8 & 9 \\
\hline 2 & 4 & 15 & 16 & \\
\hline 3 & 10 & & 12 & 11 \\
\hline & 13 & 18 & 7 & 19 \\
\hline 5 & 20 & 14 & & 6 \\
\hline
\end{tabular}

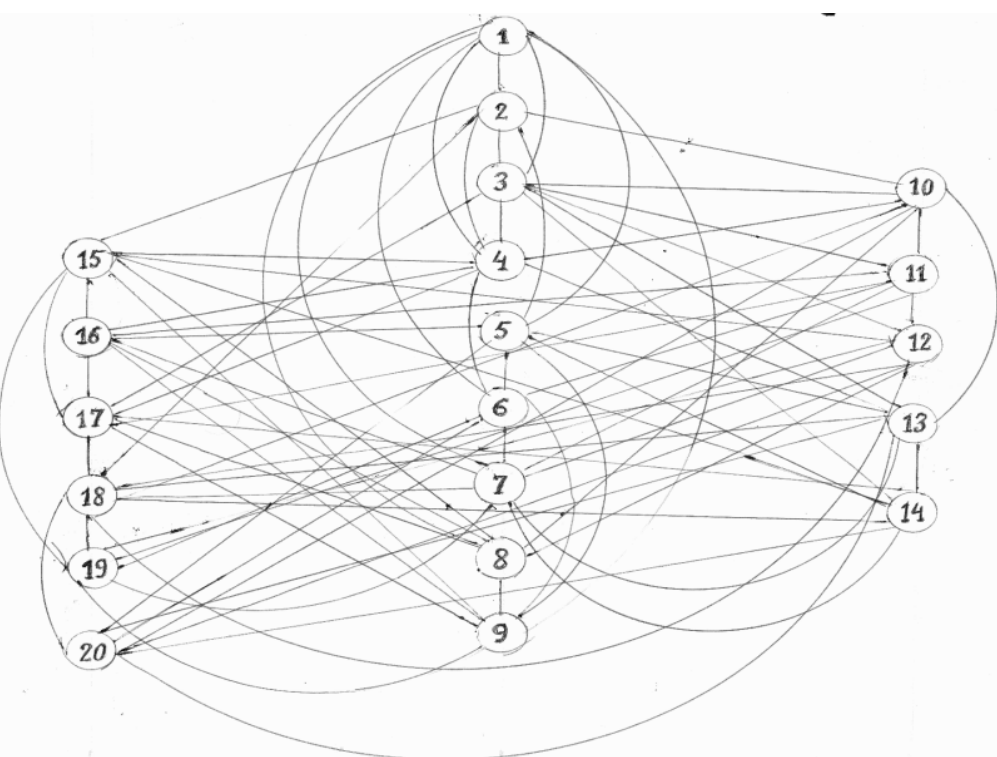

Fig. 1. Example of constructing a graph G-a symbolic image of a part working field of the cellular automaton with percolation

Here, in this fragment of the WF PCA, 20\% of voter absenteeism is displayed in the form of non-digital cells, the so-called «white cells»- defects in the 2-dimensional grid, which is why the graph $\mathrm{g}$ is constructed. The number of edges in the graph depends on the kind of surface of the WF PCA, i.e., on the boundary conditions - the nature of the crosslinking of the boundaries of the depicted square- $\mathrm{K}^{2}$-here for the torus $\mathrm{T}^{2}$.

To calculate the topological entropy, it is important to know $\mathrm{p}(\mathrm{G})$-the number of graphs $\mathrm{G}$ on the WF PCA in the case of the Moore automaton with $r=2$. Then, if the side of the WF has length $n$, and $m$ is the length of the side of the preimage $G$, then their number varies depending on the topology of the WF, f. e, for $\mathrm{K}^{2}, \mathrm{C}^{2}, \mathrm{~T}^{2}: \mid$

$$
\mathrm{p}\left(G\left(K^{2}\right)\right)=(n-m+1)^{2}, \mathrm{p}\left(G\left(\mathrm{C}^{2}\right)\right)=(n-m+1) \times(n), \mathrm{p}\left(G\left(T^{2}\right)\right)=(n)^{2}
$$

where are given the regions $\mathrm{K}$ of a 2 -square, $\mathrm{C}$ of a 2 - cylinder with an edge, and $\mathrm{T}^{2}$ of a torus. In the case of a torus, table is calculated For successively increasing fragments of the WF PCA, i.e. for graphs $G_{m}$ with an increasing number $m$ calculated Tabl.1 dependences of $\lambda 0$, i.e. the maximum eigenvalue of the adjacency matrix $\mathrm{G}_{\mathrm{m}}$ on the number $\mathrm{m}$.

Table 1. Calculation of the maximum eigenvalue values of the adjacency matrix $\mathrm{G}_{\mathrm{m}}$ from the number $\mathrm{m}$.

\begin{tabular}{|c|c|c|c|c|c|}
\hline $\mathbf{n}$ & 4 & 5 & 6 & 7 & 8 \\
\hline$\lambda_{0}(\mathbf{n})$ & 4.7 & 5.8 & 6.38 & 6.48 & 6.64 \\
\hline
\end{tabular}

Fig. 1 shows square « $4 \times 5$ » - fragment WF PCA density of white cells equal to 0.2 , i.e., significantly below the percolation threshold $\sim 0.5$. The number of vertices $|X|$ of the graph $G_{m}(X$, $\mathrm{U})$ in this case is 20 . 
To define the complexity PCA it is important to know the measure of diversity they generated trajectories. For this purpose, such an indicator as topological entropy is used. It allows you to estimate the estimate of the forecast error in the case of a random process type assumption.

Definition of topological entropy as a measure of the rate of growth of the variety of trajectories of a dynamical system. J. G. Sinai, representing a two-dimensional cellular automaton as a dynamical system with system with discrete time (D. D. S.) as a direct product of 2 commuting.

automorphisms T1 and T2, gave the example of J.Tuveno [8, p. 81] of such a system with a finite completely positive entropy. On the other hand, in [10, p. 48] it is shown that sufficient the condition for the existence of infinite positive entropy in a cellular automaton is the existence of a "spaceship". In the course of CE with the introduced PCA in this research, such a figure has never occurred. This allows us to hypothesize that this PCA has a finite completely positive entropy, which in the case of a stationary process is estimated from above $\log \lambda \max (A(G))$, where $A(G)$ is the adjacency matrix of the graph $\mathrm{G}[9]$. Or more precisely:

$$
h_{\text {top }}(f) \leq \lim _{l \rightarrow+\infty} h\left(f, C_{l}\right)=\lim _{l \rightarrow+\infty} \lim _{k \rightarrow+\infty} h\left(S\left(P_{k}\right)\right)=\lim _{l \rightarrow+\infty} \lim _{k \rightarrow+\infty} \log \lambda_{0}(A(G)),
$$

where $\mathrm{f}$ is a map of $\mathrm{PC} ; \mathrm{C}_{1}$ is a closed cover included in the sequence $\left\{\mathrm{C}_{1}\right\} ; \mathrm{S}$ is a map from $\mathrm{P}_{\mathrm{k}}$ to $\mathrm{P}_{1}$; $P_{k}$ is the space of valid paths on the symbolic image-graph $G_{k} ; \lambda_{0}=\lambda_{\max }$ is the maximum eigenvalue of the adjacency matrix $A(G)$.

\section{Theorems on completely positive finite entropy in a dynamical system of the type of the cellular automation with percolation.}

Theorem 1. If a finite Moore CA with percolation on a $\mathrm{Z}^{2}$-lattice as a lattice dynamical system on a two-dimensional oriented compact surface with discrete time has a stable stationary state, then $h_{\text {top }} P C A$ is finite and completely positive.

Evidence: 1) the Topological entropy of the PCA function according to definition (3) is calculated on a finite set (self - sufficiency of the PCA as D.D.S.) $\left\{A(G)_{m}\right\}$ of the adjacency matrices of the graph $\mathrm{G}_{\mathrm{m}}$-the symbolic image of the PCA WF.

2) Each adjacency matrix of its graph $G_{m}$ is not only nonnegative $A(G)_{m} \geq 0$, but is also bounded by the number $\mathrm{m}$, i.e., the number of vertices of this graph, which is determined only by the necessary error in displaying the simulated region.

3) According to T. Perron-Frobenius the maximum eigenvalue $\lambda 0$ of these matrices is not only real, but also limited by the inequalities: min number $\neq 0$ elements in row $A(G)_{m} \leq \lambda 0 \leq \max$ number $\neq 0$ elements in row $A(G)_{m}$. For example, in Table. 1 for $n=4$ and proper 0 values $\lambda 0: 2 \leq \lambda 0=4.7 \leq 6$

4 ) it follows that $\lambda 0$ is not only completely positive, but also finite.

5) from the proved property and definition (3) follows $0<\mathrm{h}_{\text {top }}<\infty$, duly noted.

Theorem 2. There is a threshold density of "white cells" on PCA WF above which assessment $h_{\text {top }} P C A$ finite and it is positive as would high precision of its determination was not appointed.

From the percolation theory [14, p. 15-18]), it is known that only conduction clusters with a finite number of "colored cells" exist above the threshold value for the density of "white cells".

1. From the proved Theorem 1 , for such clusters of finite number $1,0<$ htop $<\infty$ always follows fairly.

2. Setting as high accuracy as possible, due to the property of scale invariance (scaling), the inequalities given in point 1 do not change. 
Krieger's theorem: Let $\mathrm{T}$ be an ergodic automorphism, $\mathrm{h}(\mathrm{T})<\infty$.

For any $\varepsilon>0$, there is a finite generating partition $\xi$ such that $H(\xi) \leq h(T)+\varepsilon$. If $h(T)<\ln k \leq$ $\mathrm{h}(\mathrm{T})+1$ for some integer $\mathrm{k}$, then there is a generating partition of $\mathrm{k}$ elements.

This theorem shows that any ergodic automorphism with finite entropy can be realized as a stationary random process with discrete time and a finite number of States [15, p. 51]. This means that it is possible to calculate an estimate of the final forecast error and the correct length of the forecast branch [12]. In the formula below, for a Gaussian stationary process, $\sigma$ is the variance, and $\mathrm{h}$ is the entropy estimate.

$$
\sigma=2^{h-\frac{1}{2}} / \sqrt{e \times \pi}
$$

On the dependence of the PCA relaxation time on the type of two-dimensional surface for the $\mathbf{Z}^{2}$ lattice and the density of white cells. An empirical fact was established in the course of CE with PCA (see Table.2.) on the interchangeability under certain conditions of the payness of white cells and the type of surface for the $\mathrm{Z}^{2}$-lattice.

Table. 2. The dependence of the relaxation time to the balance on the density of white cells $\mathrm{d}$ and the topological genus $\mathrm{p}$ of the surface of the working field of the cellular automation.

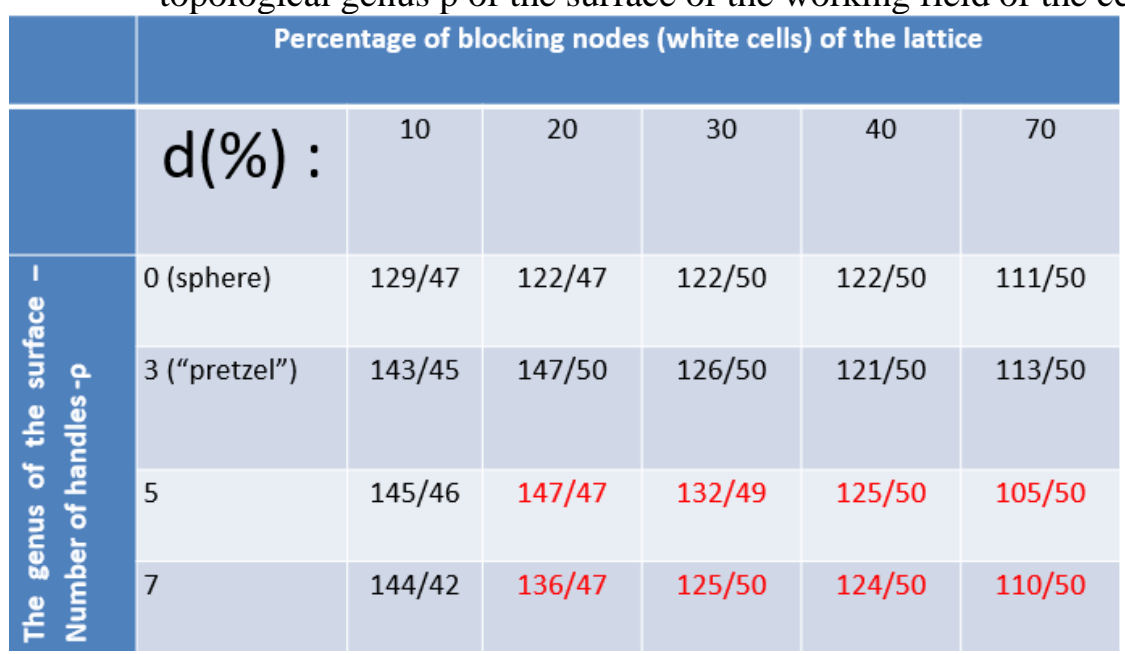

For the last two lines (this is the transition from topological genus 5 to 7 ), the "white cell" density region is selected-the range (20-70\%), where this interchangeability effect is observed. In [15], it is shown that if a vehicle has a Baker transformation, then such a vehicle has htop $=\log 2$.

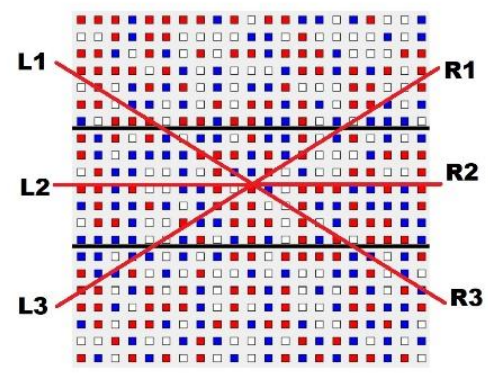

Fig. 2. The Nature of gluing the subintervals of the boundaries of the working field.

That is equivalent to setting a permutation of the 3 rd degree 
Results of applied applications of the cellular automation with percolation. The PCA made a trial, but successful, forecast of the results of the election of the President of the Russian Federation in 2018. (Fig. 3.). In this case, the non-appearance was displayed as «white cells». To start the machine, we took data from the Levada center - pro\&contra mode adherents in the Russian society [16].

Fig. 6-7 already shows the WF of PCA itself in a state of stationary equilibrium. The anamorphic distribution of the population in the Tomsk region was already taken into account here. Anamorphic representation of a two-dimensional area of population distribution means the following. As a result of its action, the areas of the depicted territories will become proportional to the corresponding values of the indicator laid down in the basis of the anamorphosis.

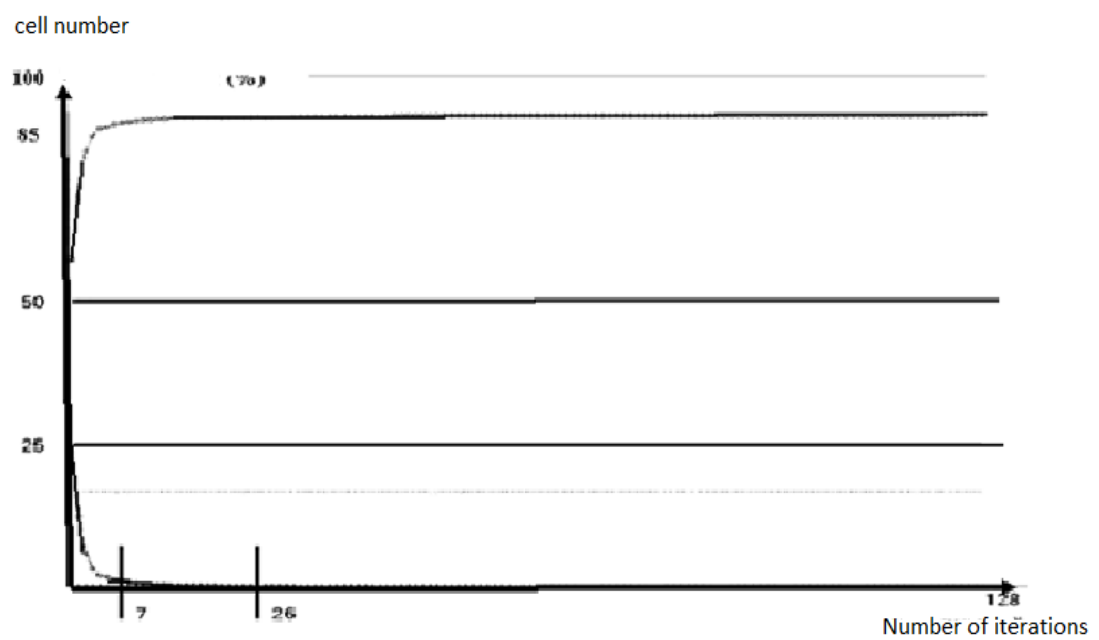

Fig. 3. Forecast of percent of vote for the presidential election (2018) - based on data from the Levada center

Transformations are required to preserve the area as much as possible. They allow you to align any densities in space, the relative location of territorial units and their shape. Anamorphoses themselves are defined as a transition from a cartographic image based on the topographic metric of the earth's surface to another image based on the metric of the mapped phenomenon.

Anamorphoses for the Tomsk region were constructed manually in accordance with the developed algorithms [17]. We proceed from the image of the simulated social locality on the map of the Russian Federation-Fig. 4.

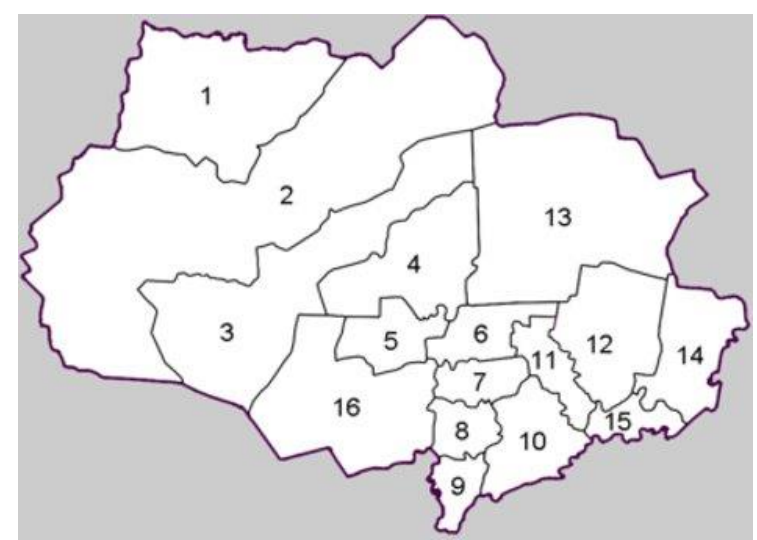

Fig. 4. Initial map image of the Tomsk region (number 10 indicates the area with the capital of the region, Tomsk) 
This approach is based on the hypothesis that despite the active development of the Internet in Russia-in rural areas, small and medium-sized cities, it is not yet developed enough to overcome the legacy of the past «trust more interpersonal relationships of the close environment than modern means of communication» on the principle - «this is not a phone conversation». The Tomsk region was chosen because it is the regional leader in terms of the number of Internet users. However, even in this area, there are 5 out of twenty districts where Internet access to the most popular services of the population is not provided. And it should also be remembered that Internet users only via mobile devices in Russia $-13.2 \%$ (16+), in rural areas $-16.4 \%$, in cities (without Moscow) - 12.7\% (Source: omnibus Gfk, 2017, all Russia, 16+).

After anamorphic transformation, which mainly preserves the topology of connections between the districts of the region, the distribution of the density of active social actors in the Tomsk region of the cellular automation with percolation looks like in Fig. 5.

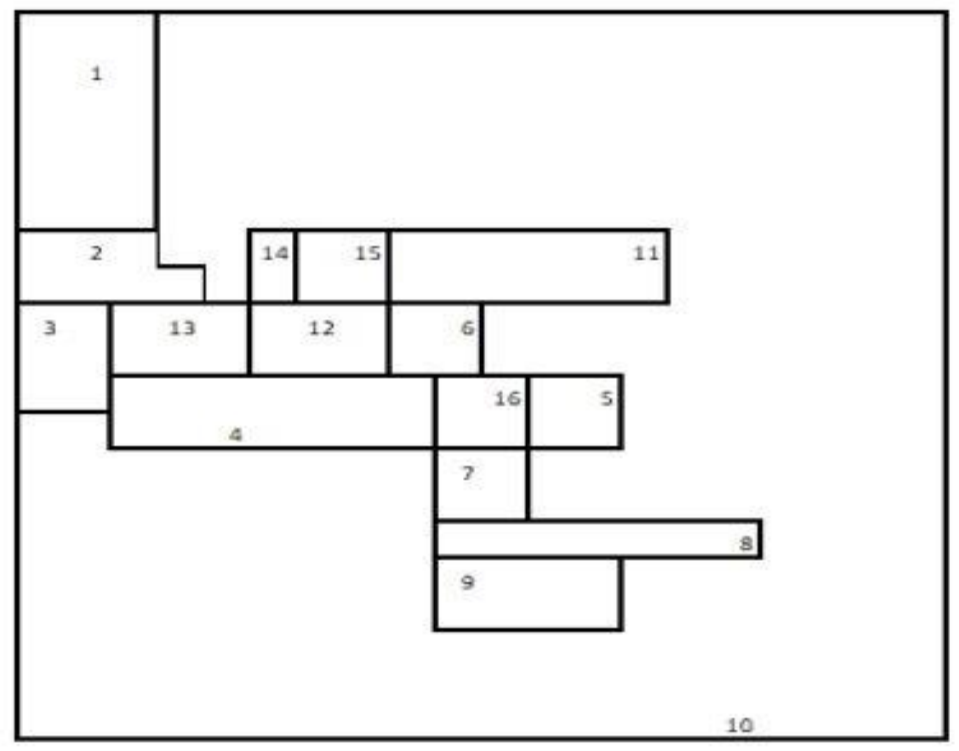

Fig. 5. Contours of placement of the socially and economically active population of the Tomsk region - anamorphic transformation
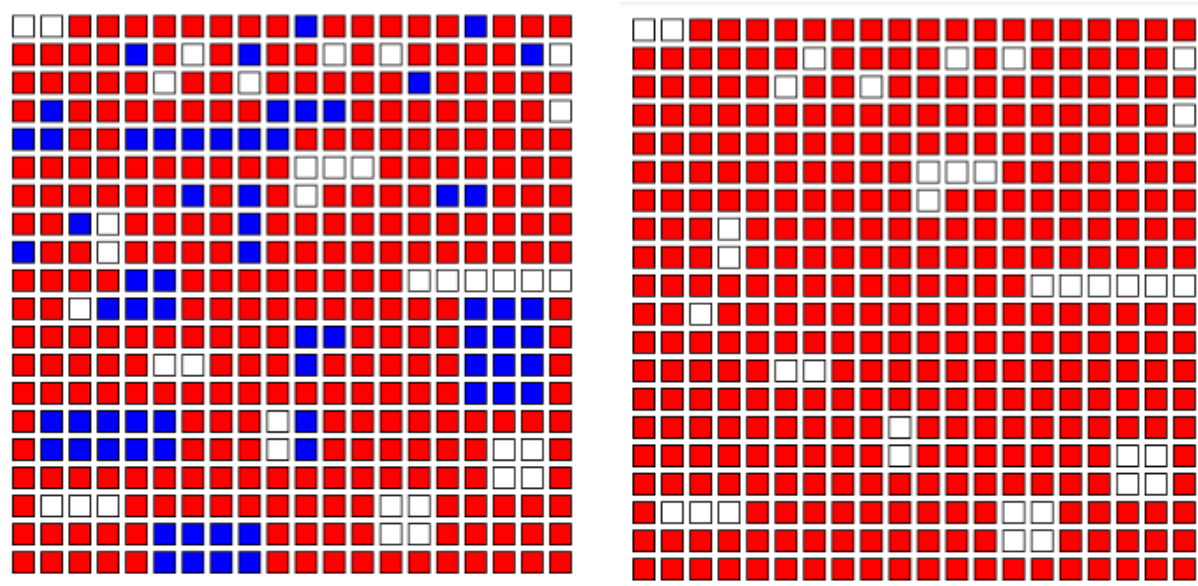

Fig. 6. Starting (left) and equilibrium (right) the cellular automation for the society of the Tomsk region with an announced no-show $10 \%$. 

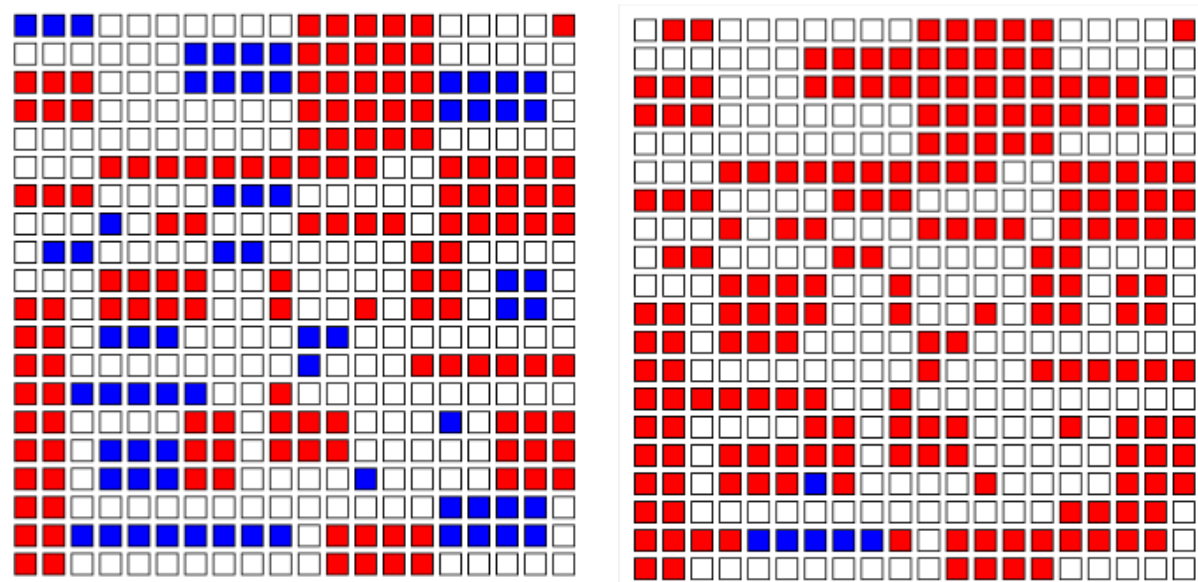

Fig. 7. Starting (left) and equilibrium (right) the society of the Tomsk region with specified no-show of 50\%.

According to the final data of the Tomsk and Novosibirsk regions, $71 \%$ of the voters who turned out to vote «for» Putin in 40-41\% [18], i.e. the forecast error was 20-24\%, which is an order of magnitude weaker than the Gallup accuracy.

This forecast error suggests that even with a pessimistic linear forecast, based on the rate of decline in the presidential approval rate after the pension reform, by 2024 , starting from $67 \%$ [13], and with a non-appearance of 50-55\%, you can get a statistically distinguishable majority of votes over the opposition, if the voters who left the "traditionalists" join the apolitical, rather than the opposition contingent.

Conclusion. We prove a theorem on a completely positive finite entropy for a percolationcellular automaton as a PC in the mode of post-threshold percolation.

The hypothesis about three main factors determining the prognosis was confirmed: the anamorphic structure of society, the prevalence and rootedness of value orientations in it.

Adequate forecasts of the results of the Presidential elections in 2018, both in the Russian Federation as a whole and in a number of regions, confirmed the effectiveness of the PCA as a forecasting tool.

The genus of the surface $\mathrm{p}$ significantly affects the percolation process: with the growth of the genus, i.e. the degree of connectivity of the society, the speed of the relaxation process to local equilibrium increases

The decrease in the density of inactive cells of the working field lattice is interchangeable with the topological type of surface $\mathrm{p}$.

Acknowledgements. I would like to thank Lomonosov Moscow state University students S. Sukhov and I. Panferova for their experiments with PCA.

The reported study was funded by RFBR according to the research project № 20-01-00229. 


\section{References}

1. A.P. Mikhailov, N.A. Marevtseva. Models of information struggle // Math. Models Comput. Simul., Vol. 4, No. 3 (2012), P. 251-259.

2. A.P. Mikhailov, G.B. Pronchev, O.G. Proncheva. Mathematical Modeling of Information Warfare in Techno-Social Environments // "Techno-Social Systems for Modern Economical and Governmental Infrastructures." (2019). IGI Global, 2019. Pages 174-210. DOI: 10.4018/978-1-5225-5586-5.ch008

3. A.P. Mikhailov, L.F. Yukhno. The formulation and preliminary study of the model of the hype dissemination of information in society // Computational mathematics and information technologies. — 2019. - No 2.

4. Petrov A. P., Maslov A. I., Tsaplin N. A. Modeling Position Selection by Individuals during Information Warfare in Society // Mathematical Models and Computer Simulations, 2016, Vol. 8, No. 4, pp. 401-408, doi:10.1134/S2070048216040141

5. A.P. Petrov, S.A. Lebedev. Online Political Flashmob: the Case of 632305222316434 // Computational mathematics and information technologies. — 2019. — No 1. - P. 17-28. doi: 10.23947/25878999-2019-1-1-17-28

6. Petrov A., Proncheva O. (2018) Modeling Propaganda Battle: Decision-Making, Homophily, and Echo Chambers // Artificial Intelligence and Natural Language. AINL 2018. Communications in Computer and Information Science, vol 930 Springer. P. 197-209. doi: 10.1007/978-3-030-01204-5_19.

7. Afrajmovich V.S. Reshyotchatye dinamicheskie sistemy. Uchebnoe posobie / V.S.Afrajmovich, V.I.Nekorkin, - Izdatel'stvo Nizhegorodskogo gos. Un.-t, - N.Novgorod, 1994.

8. Sinay Ya.G. Sovremennyye problemy ergodicheskoy teorii. - M.: Fizmatlit. 1995.

9. Ampilova N.B., Petrenko E.I. Ob otsenke entropii simvolicheskogo obraza dinamicheskoy sistemy/ / Elektr.. zhurn. Diff. uravneniya i protsessy upravleniya .- http: //www. Neva. Ru / 2008.

10. Lakshtanov E.L. Langvagen E.S. Entropiya mnogomernykh kletochnykh avtomatov //Problemy peredachi informatsii. T.42. Vyp.1 2006.

11. Osipenko G.S. i Ampilova N.B. Vvedeniye v simvolicheskiy analiz dinamicheskikh sistem: Uchebnoye posobiye. - SPb.: Izd.-vo S.- Peterb. Un-ta. 2005.

12. Shvedovskij V.A. K prognozu urovnya «doveriya institutam vlastI» s pozicij perkolyacionnokletochnykh avtomatov . // Matematicheskoe modelirovanie i informatika social'nykh processov: sbornik trudov, vypusk № 21 / Gl. red. A.P. Mikhajlov. - M.: IPM im. M.V. Keldysha, $2019-162$ s.

13. Loskutov A.Yu., Kozlov A.A. Khakhanov Yu.M. Entropiya i prognoz v teorii dinamicheskikh sistem / / Izv. Vuzov «PND». t.17. № 4. 2009. s. 98-114.

14. Tarasevich Yu.Yu. Perkolyaciya: teoriya, prilozheniya, algoritmy: Uchebnoe posobie. M.: Editorial URSS, 2002.

15. Katok A.B., Khasselblat B. Vvedeniye v sovremennuyu teoriyu dinamicheskikh sistem . M.: «Faktorial». 1999.

16. vibory-rf.ru>rezultaty...prezidenta-rossii-2018

17. S.M.Gusejn-Zade, V.S.Tikunov Anamorfozy: chto ehto takoe?. Ehditorial URSS, Moskva, 1999.

\section{Authors:}

Shvedovsky Vyacheslav Anatolyevich, Doctor of Sociological Sciences, Ph.D., Associate Professor of the Higher School of Modern Social Sciences, Lomonosov Moscow State University (Leninskiye Gory, 1, Building 33, Moscow, Russian Federation) 


\section{ПЕРКОЛЯЦИОННО-КЛЕТОЧНЫЙ АВТОМАТ КАК ДИНАМИЧЕСКАЯ СИСТЕМА: ЭНТРОПИЙНЫЙ ПОДХОД*}

\section{Шведовский В.А.}

МГУ им. М.В. Ломоносова факультет Вычислительной математики и кибернетики, Москва, Российская Федерация

$$
\square \text { mamosp@mail.ru }
$$

Построена и программно реализована модель информационного противоборства на основе двумерного перколяционно-клеточного автомата на замкнутой ориентированной поверхности. Проведены численные эксперименты. Сформулирована и доказана теорема о конечности вполне положительной топологической энтропии данного клеточного автомата. В качестве прикладного применения построенного автомата осуществлён ретроспективный прогноз результатов выборов Президента РФ в 2018 г. как в целом по России, так и в двух регионах России. Общая логика применения автомата состояла в следующем. На подготовительном этапе строилась модель региона, представляющая собой поле клеточного автомата. При этом в случае регионов использовалось анаморфозное отображение, при котором каждая территориально-административная единица отображается определенным количеством клеток, занимающим связную область поля автомата; площади этих областей пропорциональны численностям избирателей, и по возможности сохраняются географические соседства. Цвет клетки соответствует определенной политической позиции; например, если в некотором городе поддержка Президента составляет $60 \%$, то эта доля клеток этого города имеет красный цвет. В качестве начальных данных для расчета принимались результаты социологических опросов о поддержке действующего Президента, проведенных за 6-12 месяцев до выборов; динамика системы моделируется с помощью клеточного автомата; для сформировавшегося стационарного решения подсчитываются доли клеток, соответствующие количеству сторонников и противников Президента, а также неявке; эти доли принимаются в качестве прогноза результатов выборов. Построенные таким образом показали существенно более низкую точность, чем прогнозы, выполненные стандартными социологическими методами в последние дни перед выборами. Однако они могут быть применены для раннего прогнозирования. Причина такого различия состоит в том, что мнения избирателей непосредственно перед выборами определяются ходом избирательной кампании, а мнения задолго до выборов - распространённостью и укоренённостью ценностных ориентаций, которые и заложены в основу модели.

Ключевые слова: клеточный автомат, перколяция, анаморфоза, топологическая энтропия, ценностная ориентация, прогноз, индекс укоренённости кодов.

\section{Aвтор:}

Шведовский Вячеслав Анатольевич, доктор социологических наук, к. ф.-м.н., доцент Высшей школы современных социальных наук (факультет) МГУ им. М.В. Ломоносова (РФ, г. Москва, ГСП-1, Ленинские горы, д.1, стр.13).

\footnotetext{
* Исследование выполнено при финансовой поддержке РФФИ в рамках научного проекта № 20-01-00229.
} 